\title{
The Look of the Con: Eleven Thoughts on the Historical Absence of Subtitles in Film
}

\section{Analysis}

Keith M. Johnston, University of East Anglia

\begin{abstract}
This article considers the lack of dialogue between Audio-Visual Translation and Film \& Media Studies, despite the shared interests both disciplines have in the content of audiovisual texts. Structured around eleven 'thoughts' on the lack of overlap between these disciplines and the specific example of a scene from Ocean's Eleven (2001), the article looks for shared ground around ideas of authorship, genre, history, reception and audience research where more collaboration could occur.
\end{abstract}

Keywords: Film studies, authorship, genre, history, reception, audience; audiovisual translation

\section{Introduction}

Why are subtitles absent from most discussions of film analysis? Like many questions, this one feels both incredibly obvious and incredibly difficult to answer. When I was invited to bring a Film Studies perspective to the TPFF project (Tapping the Power of Foreign Language Films: Audio Translation as Cross-cultural Mediation), I had rarely considered the role that subtitles played in the historical production, distribution, exhibition and reception of films and other media - yet those four aspects of film run through my research and teaching. I was clearly aware of the existence of subtitles - I have watched many foreign-language films in my time, and the advent of DVD releases meant access to subtitles was both easier, and enabled the option of playing English language subtitles at student screenings (where English 
as a first language should not be an immediate assumption) - but they rarely featured centrally in my analysis of films. Like many Scottish people, I can remember being alternately amused and annoyed at the idea that Trainspotting (1996) would need to have subtitles added for an American release, but that wasn't necessarily the strongest starting point from which to join a debate around interlingual subtitles and film.

Involvement in the TPFF project has meant my eyes are newly open to the problems and some of the excellent scholarship in the AVT field. My route into many of these debates was the collection of essays in SUBTITLES: on the foreignness of film (Egoyan and Balfour, 2004), more specifically the piece on subtitles and trailers by B. Ruby Rich which had a direct relevance to my research. Looking at the other work in that collection, I found myself pulled further into the academic and critical scholarship on subtitles, dubbing, and other aspects of audio-visual translation, yet wondered: what did I have to offer to those debates? What research perspective or new finding could I offer that might spur this debate on? Puzzling over this led me to a new realisation: that I saw very little scholarship here that brought AVT work into dialogue with film and media studies. That is not to say that no film scholars have ever discussed subtitles. Fan Studies has been particularly interested in fan practices around subtitling or dubbing anime films or series that are not commercially available in the West (Denison, 2011), studies of transnational film have begun to explore the 'continual negotiation between the global and the local' in national cinema studies (Higbee \& Lim, 2010, p. 9; see also Bergfelder, 2005), while AVT scholarship has occasionally considered aspects of film theory and analysis (de Linde \& Kay, 1999; O’Sullivan, 2011) but there appeared to be no concerted dialogue between the disciplines, despite an interest in both the use of (often the same) audio-visual texts and the audience response to such texts.

Thinking about where the most obvious overlaps might be, I realised there was a wealth of potential - and that I didn't have one research contribution or thought to offer, I had 
many. The focus on a specific scene from Ocean's Eleven (2001) allowed me to hone that potential down, and select eleven thoughts that consider different aspects of Film and Media Studies in relation to the debates around AVT and particular aspects of that Ocean's Eleven scene. Some of these thoughts may shift across interlingual (between different languages) and intralingual (subtitling for the deaf and hearing impaired, language-learning) debates, and I may as a newcomer inadvertently stamp across such sensitivities. I think the larger points I will raise below remain applicable to both areas. While one article cannot cover all the possible avenues here, I hope the eleven thoughts I outline below can provide a useful entry point for scholars in both fields, even while I may be rehearsing and repeating debates that are more familiar to some than others. Consider these, then, as notes towards a better understanding of how film and AVT studies might cooperate and learn from each other in the future.

\section{Thought 1: Subtitles and Authorship}

In its infancy, Film Studies adopted a familiar approach to gaining scholarly and cultural respect for its largely mass-produced texts: the claiming of artistic import through the identification of film 'authors', largely through the figure of the director. From the original French critical writing on the politique des auteurs (Truffaut, 1954) through the application and expansion of that theory to the American cinema by the writers of the Movie journal and Andrew Sarris (Sarris, 1962), and the deconstruction of aspects of those authorship ideals (e.g. Wollen, 1972; Corrigan, 1991), the director remained the key visual stylist who demonstrated thematic and narrative coherence across a body of films (albeit often spotted in retrospect). Through a focus on authorship, individual artistry could be held up as the creative element that distinguished art from commercial product. (Cook, 2007, 387-89). Despite many years of scholarly work that critiqued the idea of a sole authorial voice in the industrial 
process of filmmaking (where collaboration and plurality are more common), the theory resonates within popular and academic writing to this day. Indeed, Steven Soderbergh, the director of Ocean's Eleven, is regularly referred to as the author of his films, from his low budget indie debut sex, lies, and videotape (1989) through his involvement in higher budget and more mainstream films such as the original Ocean's trilogy, Erin Brockovich (2000) and Magic Mike (2012).

While subtitles and dubbing were adopted for all these 'authors' when their films were distributed beyond the Anglophone industries, that element of their films is rarely discussed in scholarship - perhaps because the process of subtitling could be read as an imposition on top of that singular vision, an added and presumably unsanctioned layer. Subtitles also run counter to the claims made for some auteurs that they were producing 'pure' cinema that should be universally understood (and therefore, did not require additional translation). AVT studies have used the work of an auteur such as Hitchcock, particularly when a film such as Rear Window (1954) offers narrative information without dialogue (Lee, Roskos \& Ewoldsen, 2013; see also, Shochat and Stam, 1985). In the example of Rear Window, while aspects of authorship are obliquely referred to, the article is more concerned with audience response to more dialogue heavy scenes in the latter half of the film, reducing that focus on creative authorship and 'pure' cinema. This article also makes the observation that Rear Window is a film where people watch each other watching. The lack of any reference to Laura Mulvey's standard work on the male gaze is a crucial sign that this is not a film studies paper (Mulvey 1975). On the other hand, it is clear Mulvey never considered what the addition of subtitles might do to 'Screen theory', and its interest in audience's psychological identification with characters.

For my purpose, however, it is more illuminating to think what the combination of authorship studies and AVT could produce. Given the reference to Hitchcock, there might be 
a historical relevance, given his early role producing intertitles for various silent films offers an early creative act similar to subtitling. A comment from Hitchcock on silent film almost pre-empts AVT scholarly interest in how audiences respond to subtitles: 'you could change the way audiences read an action or an expression by changing the intertitle'. (Hitchcock, quoted in Kerzonkuf and Barr, 2015, 17) If subtitling is seen as an act of creative imposition onto a director's work, what would it mean to bring those two theories together and explore that contradiction?

\section{Thought 2: Genre and Subtitles}

In the Star Trek film and television universe, it is not uncommon to have alien languages such as Klingon or Ferengi translated on screen, despite the in-universe concept of a universal translator that converts all alien languages back into English, itself, an ideological statement about the correct language for interstellar communication. In The Lord of the Rings (2001-2003) and The Hobbit (2012-2014) film trilogies, the languages of Elves, Dwarves, Orcs and other species were also translated via on-screen subtitles. There appears to be a distinction here between different generic understandings and appropriation of subtitles, suggesting there might be something specific about the science fiction and fantasy genres utilising subtitles (for an English-speaking audience in the first instance) as an accepted narrative device that is integrated into the world-building of such franchises. The long production history here also suggests this is now established practice; in contrast to, say, dramas and romantic comedies where such subtitling use is less prevalent, because they are genres that rely more heavily on 'real world' situations driven by dialogue and wordplay.

That is certainly true of the Ocean's Eleven scene that, although it bears few signs of the con/heist sub-genre of the crime film, places its action in a recognisable milieu that is broadly understood as contemporary America and Las Vegas. There are no alien characters 
whose words need translation, and one of the few instances of non-English dialogue is the film's Chinese character Yen (Shaobo Qin) who rarely speaks at all, and when he does speak Mandarin the words are largely untranslated. (Gallagher 2006, 278) The generic identity of Ocean's Eleven is not really concerned with genre-specific dialogue (as would be the case in science fiction or fantasy), with most of the film's generic reference being visual: the look of the con, the preparations, casinos, and the star performances of its cast. That suggests there could be more interest here in considering the difference between genre films that adopt subtitles for fantastic species as a necessary narrative device (as well as featuring interlingual subtitles), those that do so for 'aesthetic or political reasons' (O'Sullivan 2007, 81), versus those such as Ocean's Eleven where interlingual subtitling is needed solely for international distribution.

\section{Thought 3: Subtitles and Performance}

Studies of stardom and performance understandably focus more on the visual and aural qualities of the actors in question (their look, accent, manner) rather than the ability of subtitles to capture those qualities. The performance of Bernie Mac, who plays Frank Catton in Ocean's Eleven, has been described as one of 'aggrieved blackness', used in a specific casino-set sequence 'to control... a contested space' (Gallagher, 2006, 278). Mac's star persona (he was a well-known stand-up comedian, television and film performer before his appearance here) arguably dominates the Ocean's Eleven clip under discussion, and although there is no overt display of the 'camouflage of racism' that Gallagher has identified, it is worth considering the different qualities of his performance as Catton and whether the subtitles are able to convey the aspects of that performance that go beyond his words.

Despite the initial cordiality of the exchange between Mac and car salesman Billy Tim Denham (Joe LaDue), the performances convey underlying tensions that are not 
restricted to the dialogue (which, at first glance, feels anodyne). First, Denham's half-worried glances off-screen (to where two other members of the crew are bouncing on the back of a van) demonstrate how the con artists are working to distract him; meanwhile, Mac's earnest discussion of hand creams belies the harder edge of the real negotiation - which is found in the (prolonged) handshake, which the film cuts to twice to underline its (unspoken) importance. Mac's cheery discussion of cream, his dislike of gloves, and his 'social agenda' offers a link back to Gallagher's discussion of a performance of a specific stereotype of blackness, although here it is more suggestive of sexuality than violence. Mac's vocal performance paints Catton as a reasonable and chatty individual, while the physical performances - not least Mac's physical dominance of the reverse-shot structure that shows him and LaDue together - tell a different visual story. This builds to the point where Denham offers to drop the price and, with a wince (caused by an unseen tightening of Mac's hand that happens below the frame), gives a lower figure. Mac finally releases his hand. The performances have built up a tension that is counterpointed by seemingly innocuous dialogue, yet both work to underline Catton's dominance over Denham. Watching with the subtitles on may have put undue stress on the dialogue elements, when it is really the performance that conveys story and character detail. While there may be a clearer link here with how dubbing changes the aural dimensions of a performance (Bosseaux 2015), the link between subtitle and performance and stardom seems to be largely unexplored.

\section{Thought 4: Subtitles and Film \& Media History}

The origins of the subtitle are often cited in AVT work, with Egoyan and Balfour claiming it can be traced back to 'as early as $1907 \ldots$ in the era of the intertitles, but it did not really come into its own until the age of the talkies and their international distribution' (Egoyan \& Balfour, 2004, p. 22). As noted above, Alfred Hitchcock - along with many other writers and 
directors - made his start producing scenarios and adaptations for the silent screen, writing intertitles that propelled the story on. Yet that transition from an industrial expectation of intertitle (as proto-subtitle) to the production of subtitles for international distribution is, to the best of my knowledge, absent from most histories of the 1930s. As a historian, it would be fascinating for me to understand how the subtitling for a film such as Ocean's Eleven fits within that history, whether there are aesthetic approaches taken within this scene that either challenge or conform to existing industrial practice. While some AVT work has begun to do this (O'Sullivan and Cornu, 2018), it is clear that this is an important industrial history (nationally and globally), and the lack of connection with broader film histories seems to speak to a lack of dialogue between the disciplines.

\section{Thought 5: Sound and Image and Subtitles}

Sound in film analysis has been described as 'the poor relation in Film Studies, because of the primacy of the visual for theorists of spectactorship' (Stillwell \& Powrie, 2006, xii), offering a potent parallel to the subtitle. The complexity of soundtrack elements is often further diminished due to the point where "the term "soundtrack" has come principally to signify the music track of a film, dialogue being confined to another - "superior" - realm, that of the screenwriter.' (Sergi, 1998, p. 157) Returning to a point discussed above, the Ocean's Eleven scene underlines both the visual dominance of film analysis - to the point where my earlier discussion of performance almost dismissed the dialogue exchange, despite its clear importance and additional layering to the performance - but also suggests the prominence given to dialogue by both the spoken words and the subtitles translating them. In this sense, the subtitles partly reinforce Sergi's claim that dialogue is made superior in relation to other aspects of the soundtrack. 
While sound has become more of a presence within film, television and media studies over the last two decades, its relationship to the subtitle remains unexplored, beyond the translation and interpretation of dialogue. How do music, sound effects and silence affect the work of the subtitler, or the aesthetic effect of the subtitles themselves? More analysis of the relationship that can be formed between these aural and visual elements - as well as the other elements on screen - could be a fruitful area to explore further, and collectively.

\section{Thought 6: Subtitles vs. On-Screen (Diegetic) Text}

As was suggested in my opening remarks, there are many English-language film and media scholars like myself who simply do not think academically about subtitles. While they are actively consuming audio-visual material made for the language they speak (English), unless they require subtitles for the hearing impaired, interlingual subtitling is simply not in their thoughts. As indicated, that included my inadvertent elision of subtitles from my own research on English-language film and television, particularly around British cinema. Yet as with the example of genre subtitles above, there is a clear area within film production that uses titles (and I choose the word carefully, as they are clearly not subtitles) diegetically and as part of the narrative. Here, I am thinking of the likes of 'England, 1973' as a caption in a flashback, or the multiple words that flash on screen during an episode of Sherlock (20132017). (Dwyer 2015) Such usages of on-screen text are seen as narratively necessary for all viewers, and therefore fit within dominant understandings of genre, authorship, and production practices already discussed above.

This appears to create a hierarchy within production and reception, then, where onscreen text added by the original creative team is acceptable; while subtitles that are added later, often by a different individual, is less privileged because of the perceived distance from the source of the creative text. This seems to cycle back to debates on authorship again, and 
who is 'allowed' to add written text on to the narrative screen: the editor who works on a television programme or film who is authorised by being part of that creative team, or the subtitler, who has little or no power or acknowledgement within that same team. In the example of Ocean's Eleven, for instance, I wonder about the relationship of Pacific Title ('Titles and Digital Opticals', in the film's official credits at 1:50:20 49) to 'SDI Media Group' (over the final Warner Bros. logo at 1:51:45). Given the latter's credit ('Subtitles by') exists outside the official credits roll, and has been added in a different font from the other credits, it again underlines the official / unofficial nature of the relationship. Again, I doubt such thoughts are unique to the AVT community, but it would behove film and television scholars to consider more closely the different kinds of media labour that underpin these different aspects of on-screen text.

\section{Thought 7: Subtitles and (Invisible) Industry}

Linked to that thought, the last ten to fifteen years has seen a significant rise in ethnographic studies of the media and creative industries. Part of that has been a push to reconsider and reveal often invisible careers and histories that need to be understood within those industries: rethinking gender, race and ethnicity issues across multiple sectors has been a particular focus here, alongside calls to pay more attention to 'below the line' positions within the industry that are traditionally overlooked, at least in part because of the dominant focus on the writer, director and producer (Hesmondhalgh and Baker, 2011; Caldwell, 2008; Deuze, 2007). AVT scholars have begun to open up that side of the industry (Behar, 2004), and it would be fascinating to bring those two parallel paths into dialogue. In the case of the scene from Ocean's Eleven, it would be relatively simple to track down the name of the editor or the production designer who contributed to a particular aspect of that scene; in terms of the 
subtitles, that labour seems even more invisible and disconnected from the main act of creation.

\section{Thought 8: Subtitles and the Archive}

As a film and media historian, one of my first thoughts was around the archiving of original subtitles. Films and television programmes (and many other media) have suffered from insufficient archival attention over the decades, with many films and TV programmes simply lost for good. The focus of many archive initiatives has been led by traditional approaches famous directors, genres, canonical film titles - but also by a desire to ensure the best available picture and sound information is preserved and, in the world of $21^{\text {st }}$ century archiving, digitised in different scan rates. Yet the additional element that does not seem to be considered here remains the historical example of subtitling that was added for the original distribution and exhibition. Where is that archived?

The Ocean's Eleven DVD offers one form of archive, but are the subtitles available on the DVD the same as those that were made available during the theatrical release of the film? How do the subtitles made by SDI Media for the English language subtitles on the Ocean's Eleven DVD differ from the original cinema release? Does it matter if the film is archived without the full range of original subtitles, preserving only the English audio-visual version? Linked to the idea of media labour expounded across the last two 'thoughts', it seems likely that such creative endeavour is being lost, largely through dominant assumptions about the 'core' text that is being archived.

\section{Thought 9: Subtitles and Aesthetics}

Textual analysis of film regularly focuses on aspects of the mise-en-scene: those elements of set, costume, lighting, and camerawork that portray the visual narrative of the film (and, as 
noted above, much of this analysis is focused on the visual). One element of that is the use of colour, although until recently that has remained an under-researched area of film aesthetics (Street, 2012). Thinking of colour in relation to the Ocean's Eleven sequence, the use of red is probably most suggestive - Mac's jacket is red, there is red-and-white bunting outside and inside the car showroom, red cards in the lot, a red desk and red lettering behind Denham's head. Indeed, Denham's hand becomes increasingly red during the handshake he has with Catton. Rather than jump to easy assumptions around red and danger (or anger, or sexuality), its use here is interesting because the rest of the film is more balanced in its colour aesthetic.

The different subtitling options available for this scene (and the film in general) also rely on white subtitles over the live action. White text is clearly a preferred option for many subtitles, but the use of different colours to represent different characters is an aspect of the aesthetic presentation of subtitles that feels ripe for more interdisciplinary work around the culturally-specific codes and conventions around colour that might influence such choices. Following the idea of a 'creative turn in subtitling' (McClarty 2012, 135), it seems to be a place where a more textually-focused approach to the visual aspects of a film might also be applicable to the presentation of subtitles as well.

\section{Thought 10: Subtitles and Reception}

Thinking about the reception of subtitles, which is clearly a long-standing debate within AVT, causes me to reflect on the absence of critical reception work that considers subtitles. Critical reception studies' focus on how critics helped shape cultural opinion on film and taste cultures has, to the best of my knowledge, not been used to consider the wider discourse on subtitles. In part this might be because critical reception tends to look for wider cultural issues, or events, rather than comments on the quality or effectiveness of subtitles. Many of these relate to issues discussed above, with reception studies offering strong case studies 
about shifting attitudes to genre (Jancovich, 2000; Mathijs, 2005) and authorship (Klinger, 1994). A standard approach to, say, Ocean's Eleven might consider critical response to Soderbergh, discussions of the cast in general, or specific (in terms of George Clooney or Brad Pitt's career). Developing a wider critical reception study that considered what discourse currently exists around subtitles would be one step that brought methodologies and skills from both film \& media and AVT closer together.

\section{Thought 11: Subtitles and Audiences}

My final thought, then, brings me back to the first AVT workshop I attended, and a discussion on what, and how, to research the audience. It is also a place where the gap between the disciplines might be most usefully filled, drawing together unresolved questions from AVT and qualitative research methods from Media Studies. One key issue here would seem to be the lack of any significant research on general attitudes to subtitles from audience members, both in terms of cinema and home video use. Many large-scale audience studies have looked at audience response and attitudes to large franchises such as Lord of the Rings (Mathijs, 2006; Barker and Mathijs, 2008) or The Hobbit (Davis et al., 2014) around issues of expectation, narrative involvement, and emotional investment. While there has been a growth of interest around audience studies, not least in relation to more fan- and franchise-centric research, it has been noted that studies of the audience remain neglected within transnational film studies. Given this is one area where crossover work around film analysis and subtitles could arise, the call to 'examine the capacity of local, global and diasporic audiences to decode films as they circulate transnationally' (Higbee \& Lim, 2010, p. 18) is one that should also include a closer interaction with colleagues well-versed in audio-visual translation. While there has been recent progress in developing reception studies and AVT (Di Giovanni 
and Gambier 2018), expanding more audience-based work seems a potent area for collaboration.

\section{Conclusion}

I should start by acknowledging that these eleven thoughts, briefly sketched out and considered above, are simply the ones that felt most obvious to me. As a scholar most interested in debates around British cinema, technology, genre, marketing and reception, I may not have the best perspective from which to understand those places where AVT might have crossed over with film and media studies. Yet even the partial survey of existing literature that I looked at to frame my thoughts here pointed towards these areas as parallel tracks, sharing some common interests but rarely informing the other. It is clear that recent work may offer answers to some of my queries about subtitling history, labour and archiving (e.g. Sullivan and Cornu, 2019; Romero-Fresco, 2019), but there remains more that could be done to cross those tracks. This raises the difficulty of developing any interdisciplinary pursuits, particularly those that require new methodological or theoretical perspectives to be taken, or existing ones to be challenged. It is somewhat ironic, then, that for most of the suggestions I have offered above to be developed, the key lies in adequate and appropriate translation.

\section{Disclosure statement}

No potential conflict of interest was reported by the author.

\section{Notes on Contributor}

Keith M. Johnston is Professor of Film \& Television Studies at the University of East Anglia. His research focuses on the interplay of technology, aesthetics and industry in British cinema, 
including Ealing Studio's use of colour (1948-57), the history and reception of British stereoscopic 3-D (1950s and modern), and special effects in 1940s Ealing films. His parallel research interests include film marketing, most notably the history and development of the film trailer. He is the author of Coming Soon: Film Trailers and the Selling of Hollywood Technology (McFarland \& Co, 2009), Science Fiction Film: A Critical Introduction (Berg, 2011), and co-editor of Ealing Revisited (BFI/Palgrave Macmillan, 2012). His current research is on the introduction of Eastmancolor, as co-investigator on the AHRC-funded project, 'The Eastmancolor Revolution and British Cinema, 1955-85'.

\section{References}

Barker, M., \& Mathijs, E. (Eds.) (2008). Watching the Lord of the Rings: Tolkien's World Audiences. New York: Peter Lang.

Béhar, H. (2004). Cultural Ventriloquism. In A. Egoyan \& I. Balfour (Eds.), SUBTITLES: on the foreignness of film (pp. 79-86). Cambridge, MA: The MIT Press/Alphabet City Media.

Bergfelder, T. (2005). National, transnational or supranational cinema? Rethinking European film studies. Media Culture and Society 27 (3): 315-331.

Bosseaux, C. (2015). Dubbing, Film and Performance: Uncanny Encounters. Bern: Peter Lang.

Caldwell, J. (2008). Production Culture: Industrial Reflexivity and Critical Practice in Film and Television. Durham, NC: Duke University Press. 
Cazdyn, E. (2004). A New Line in the Geometry. In A. Egoyan \& I. Balfour (Eds.), SUBTITLES: on the foreignness of film (pp. 403-419). Cambridge, MA: The MIT Press/Alphabet City Media.

Corrigan, T. (1991). A Cinema without Walls: Movies and Culture After Vietnam. New York: Routledge.

Davis, C., Michelle, C., Hardy, A. and Hight, C. (2014). Framing audience prefigurations of The Hobbit: An Unexpected Journey: The roles of fandom, politics and idealised intertexts. Participations: The Journal of Audience and Reception Studies 11 (1), 50-87.

de Linde, Z. \& Kay, N. (1999). Processing Subtitles and Film images. The Translater 5 (1), 45-60.

Denison, R. (2011). Anime Fandom and the liminal spaces between fan creativity and piracy. International Journal of Cultural Studies 14 (5), 449-465.

Deuze, M. (2007). Media Work. Cambridge: Polity Press.

Di Giovanni, E. \& Gambier, Y. (2018) (eds.). Reception Studies and Audiovisual Translation. Benjamins Translation Library 141.

Dwyer, T. (2015). From Subtitles to SMS: Eye Tracking, Texting and Sherlock. Refractory: a Journal of Entertainment Media. http://refractory.unimelb.edu.au/2015/02/07/dwyer/ 
Egoyan, A. \& Balfour, I. (2004). Introduction. In A. Egoyan \& I. Balfour (Eds.), SUBTITLES: on the foreignness of film (pp. 21-30). Cambridge, MA: The MIT Press/Alphabet City Media.

Gallagher, M. (2013). Male Style and Race in the Neoretro Heist Film. In T. Shary (Ed.) Millennial Masculinity: Men in Contemporary American Cinema (pp. 265-287). Detroit: Wayne State University Press.

Hesmondhalgh, D. \& Baker, S. (2011). Creative Labour: Media Work in Three Cultural Industries. Abingdon, Oxon: Routledge.

Higbee, W. \& Lim, S.H. (2010). Concepts of transnational cinema: towards a critical transnationalism in film studies. Transnational Cinemas 1 (1), 7-21.

Jancovich, M. (2000). 'A Real Shocker': Authenticity, genre and the struggle for distinction. Continuum: Journal of Media and Cultural Studies 14 (1), 23-35.

Kerzoncuf, A. \& Barr, C. (2015). Hitchcock Lost and Found: The Forgotten Films. University Press of Kentucky.

Klinger, B. (1994). Melodrama and Meaning: History, Culture and the Films of Douglas Sirk. Indiana University Press.

Lee, M., Roskos, B. \& Ewoldsen, D. R. (2013). The Impact of Subtitles on Comprehension of Narrative Film. Media Psychology 16 (4), 412-440. 
Mathijs, E. (2005). Bad reputations: the reception of 'trash' cinema. Screen 46 (4), 451-472.

Mathijs, E. (2006) (ed.). The Lord of the Rings: Popular Culture in Global Context. London: Wallflower.

McClarty, R. (2012). Towards a multidisciplinary approach in creative subtitling. MonTI 4: $133-153$

Mulvey, L. (1975). Visual Pleasure and Narrative Cinema. Screen 16 (3), 6-18.

Naficy, H. (2004). Epistolarity and Textuality in Accented Films. In A. Egoyan \& I. Balfour (Eds.), SUBTITLES: on the foreignness of film (pp. 131-151). Cambridge, MA: The MIT Press/Alphabet City Media.

O’Sullivan, C. (2007). Multilingualism at the multiplex: a new audience for screen translation? Linguistica Antverpiensia 6: 81-95.

O’Sullivan, C. (2011). Translating Popular Film and the intercultural imagination. Basingstoke: Palgrave Macmillan.

O’Sullivan, C. \& Cornu, J-F (2019) (Eds.). The Translation of Films 1900-1950. Oxford: Oxford University Press. 
O’Sullivan, C. \& Cornu, J-F (2018). History of Audiovisual Translation. In L. Pérez González (ed.) Routledge Handbook of Audiovisual Translation. London: Routledge.

Romero-Fresco, P. (2019). Accessible Filmmaking: Integrating translation and accessibility into the filmmaking process. London: Routledge.

Sabanev, L. (2011). The Aesthetics of the Sound Film (1935). In J. Hubbert (Ed.), Celluloid Symphonies: Texts and Contexts in Film Music History (pp.213-220). Berkeley: University of California Press.

Sarris, A. (1968). Notes on the Auteur Theory in 1962. Film Culture 27, 1-8.

Shochat, E. \& Stam, R. (1985). The Cinema After Babel: Language, Difference, Power. Screen $26(3-4): 35-58$.

Sergi, G. (1998). A cry in the dark: The role of post-classical film sound. In S. Neale \& M. Smith (Eds.), Contemporary Hollywood Cinema (pp. 156-165). Abingdon: Routledge.

Sinha, A. (2004). The Use and Abuse of Subtitles. In A. Egoyan \& I. Balfour (Eds.), SUBTITLES: on the foreignness of film (pp. 171-190). Cambridge, MA: The MIT Press/Alphabet City Media.

Stilwell, R. \& Powrie, P. (2006). Introduction. In P. Powrie \& R. Stilwell (Eds.), Changing Tunes: The Use of Pre-Existing Music in Film (pp. xii-xix). Aldershot: Ashgate. 
Street, S. (2012). Colour Films in Britain: The Negotiation of Innovation 1900-55. London:

British Film Institute/Palgrave Macmillan.

Truffaut, F. (19). Une Certaine Tendance du Cinéma Français. Cahiers du Cinema 31, 13-17.

Wollen, P. (1972). Signs and Meanings in the Cinema. London: Secker and Warburg.

\section{Audio-Visual Media}

Boyle, D. (1996). Trainspotting. UK: Channel 4 Films.

Hitchcock, A. (1954). Rear Window. USA: Paramount Pictures.

Gatiss, M, Moffat, S, Vertue, B, \& Vertue, S. (Producers). (2010-2017) Sherlock. UK: BBC

Wales \& Hartswood Films.

Jackson, P. (2001). The Lord of the Rings: The Fellowship of the Ring. USA \& New Zealand: New Line Cinema.

Jackson, P. (2002). The Lord of the Rings: The Two Towers. USA \& New Zealand: New Line Cinema.

Jackson, P. (2003). The Lord of the Rings: The Return of the King. USA \& New Zealand:

New Line Cinema.

Jackson, P. (2012). The Hobbit: An Unexpected Journey. USA \& New Zealand: New Line Cinema \& Metro-Goldwyn Mayer.

Jackson, P. (2013). The Hobbit: The Desolation of Smaug. USA \& New Zealand: New Line Cinema \& Metro-Goldwyn Mayer.

Jackson, P. (2014). The Hobbit: The Battle of the Five Armies. USA \& New Zealand: New Line Cinema \& Metro-Goldwyn Mayer. 
Roddenberry, G. (Producer) (1966-present). Star Trek [Television series]. USA: Desilu Production \& Paramount Television.

Soderbergh, S. (1989), sex, lies, and videotape. USA: Outlaw Productions \& Virgin.

Soderbergh, S. (2000), Erin Brockovich. USA: Universal Pictures \& Columbia Pictures.

Soderbergh, S. (2001). Ocean's Eleven. USA: Warner Bros.

Soderbergh, S. (2012). Magic Mike. USA: Iron Horse. 